\title{
The Use of Internet Banking in the Czech Republic
}

\author{
Martina Hedvicakova, Libuse Svobodova \\ University of Hradec Králové, Faculty of Informatics and Management, Rokitanskeho 62, 500 \\ 03, Hradec Kralove, Czech Republic \\ Martina.hedvicakova@uhk.cz, Libuse.svobodova@uhk.cz
}

\begin{abstract}
Internet and mobile banking is becoming more important worldwide. New technologies have huge impact for the introduction of new functionalities in both internet and mobile banking. Growth of Internet users and smartphones also has an impact on this growth. The Czech Republic was using internet banking above the European Union average in 2017. In the European Union $51 \%$ of individuals used internet banking and 57\% of individuals in the Czech Republic. The main aim of the article is to analyze the situation in the use of internet banking in the Czech Republic by the number and percentage of individuals and by age, gender and education. The second part of the article is focused on the analysis of ten banks with the largest number of clients in the Czech Republic, where they analyze the latest and most needed features of their mobile banking from the client perspective. The last part focuses on the use of social networks by banks. The article uses primary and secondary data.
\end{abstract}

Keywords: Internet Banking, Mobile Banking, Functions, Bank, Social networks

\section{Introduction and current situation}

With the sky rocking number of smartphone users and popularizing of internet worldwide, there with the phenomenal growth of e-banking transactions through mobile phones. According to a recent forecast (Internet world, 2015) [1].

Mobile and Internet Banking has a great contribute in online banking revolution, which is giving a competitive edge to the banks against their rivals. Especially "Transaction Alert / Confirmation" is most demanding service by users. Customers feel that after monetary transaction the SMS should be received, and they prefer the version of the IVR (Interactive Voice Response) banking service that provides (outof-band) SMS confirmation over those one that does not [2]. Therefore, online banking helps banks to retain and enhance the loyalty of their existing customers, increase customer satisfaction, provide opportunity to the banks to increase market share, reduce administrative and operational cost and to improve banks' competitive positions against their rivals [3-5].

The popularity of Internet banking is growing worldwide. Internet banking is the only activity that students use to a lesser extent than the average population (of the monitored population). 


\section{The literature review}

The market for banking services in the Czech Republic is characterised by high competition. The market was recently joined by four new 'low-cost' banks which opted for an offensive pricing strategy to enforce themselves. [6] One of the ways to keep the number of clients for existing banks is Internet and Mobile banking.

The Promotion of online banking technology enabled the banks to enhance its operations with cost cutting effectively and efficiently in order to handle daily banking affairs via online banking channel. Customers are being facilitated by reducing their visits in banks and they can carryout their transactions via internet or ATM Machines instead of personally visiting the branches. [5].

With the growth of using e-banking transactions through mobile phones in China, it brings along with convenience of people's life as it enables people to have access to banking services anywhere and at any time as well as it conducts business more effectively. [7].

When the consumer has a market overview then the optimal product can be chosen more or less easily. Soukal and Draessler [8] model more realistic situation where the consumer does not have a market overview and so the process of search has to be performed. The harder the search is the higher information asymmetry is. Currently, clients decide how according to the charges for current account and primarily by the level of Internet and Mobile Banking. Customers are particularly interested in the features to help control and manage their accounts.

In the last decade, Internet banking technology has made remarkable progress. However, there is a huge disparity across different nations all over the world in the diffusion of Internet banking services. This leads to the research question of Takieddine and Sun [9] study: why different countries exhibit different levels of Internet banking adoption? We will focus on the situation of Internet Banking in the Czech Republic. Regarding technological readiness the Czech Republic is doing better than the other Visegrad countries. Citizens are technological equipped and they have competencies to use ebanking. [10] Černohorská et al. [11] examine the comparative performance of Banks for the Visegrad group (V4) of four Central European States for the period 20092013.Their results showed that average technical efficiency (for all banks) trended upward during the study period. This increase efficiency is not common for all banks in the Czech Republic, Poland, Hungary and Slovak. They found that efficiency for Czech, Polish and Slovak banks increase during research time. Development of efficiency Hungarian banks has on the contrary a downward trend from 0.882 in 2009 to 0.856 in 2013. We also founded that the Total Factor of Productivity (TFP) changes across all countries was relatively stable in 3 of the 4 observation periods.

Smaller firms, however, invested more in research and development (R\&D) and Vokoun [12] was found no linear relationship for output characteristics.

\section{The goal of article and methodology}

The article is based on primary and secondary sources. Secondary sources comprise information about Internet Banking in the Czech Republic and European Union, 
professional literature, information collected from professional press, discussions or previous participations in professional seminars and conferences relating to the chosen subject. Primary resources are based on information obtained from the web portals of individual banks in the Czech Republic. Then it was necessary to select, classify and up-date accessible relevant information from the numerous published materials that would provide the basic knowledge of the selected topic. [13].

The goal of the article is to focus on the Internet Banking in the Czech Republic and its position within the European Union. The second part of the article analyzes new features in mobile applications at the top ten banks according to the number of clients in the Czech Republic. The last part focuses on the use of social networks by banks. The article uses primary and secondary data.

\section{$4 \quad$ Internet banking in European Union}

By 2017, the share of EU-28 households with internet access had risen to $87 \%$, some 32 percentage points higher than in 2007.

Broadband internet access was used by $85 \%$ of the households in the EU-28 in 2017, approximately double the share recorded in 2007 (42 \%). [14].

Figure 1 shows that on average $51 \%$ individuals aged 16-74 used Internet banking in in European Union in 2017. This share is constantly increasing and has doubled since 2007, when it stood at $25 \%$.

Internet banking is particularly popular among 25 to 34 year olds, with $68 \%$ using this facility. The use of internet banking tends to increase in line with the education level of the user. While only $24 \%$ of those with low education use e-banking, $77 \%$ of those with high education use this service.

Among EU Member States, internet banking is most common in Denmark (where $90 \%$ of people aged 16 to 74 said they were using it) and the Netherlands (89\%), followed by the other Nordic countries - Finland (87\%) and Sweden (86\%).

The lowest shares were registered in Bulgaria (5\%) and Romania (7\%). Less than $30 \%$ of those between the ages of 16 and 74 use internet banking in Greece (25\%) and Cyprus (28\%). [15].

Internet Banking is second less popular among the youngest ones. Only $44 \%$ of younger internet users performed some kind of electronic transactions with a bank (for payment, transfers, etc. or for looking up account information) against $55 \%$ aged 5574 and $65 \%$ aged 25-54 in 2016. [16]. 


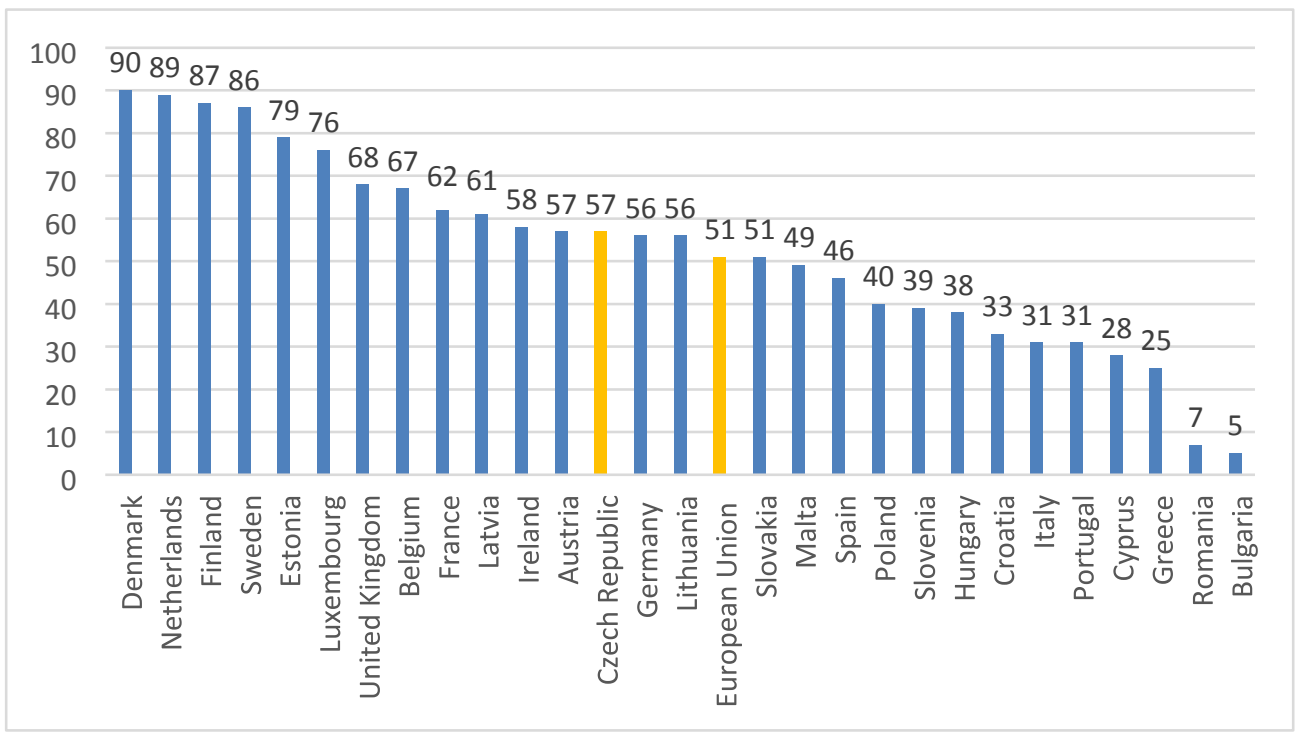

Fig. 1. People who used Internet banking in 2017 (\% of individuals aged 16-74), Source: Eurostat [15], own processing

More and more people use Internet banking in the Czech Republic. Internet Banking was used by 3.9 million individuals in 2015 and by 20174.5 million people. The Czech Republic has 10.6 million inhabitants. Figure 1 shows that the Czech Republic is above the EU average and 57\% of individuals used Internet banking in 2017.

\section{The results of the Internet Banking in the Czech Republic}

\subsection{Internet Banking in the Czech Republic}

Figure 2 shows individuals using Internet Banking in the Czech Republic. Only 0.9 millions of Individuals used the Internet Banking in 2007. About 10 years later used the Internet Banking 4.5 millions of Individuals from 10.6 millions people in the Czech Republic.

$11 \%$ of individuals used Internet Banking in the Czech Republic in 2007. In 2011, internet banking was used by $27 \%$ of individuals, by over $38 \%$ for two years. In 2015 , growth slowed down, and Internet Banking was used by only $45 \%$ of individuals. $52 \%$ of individuals used Internet Banking in 2017 


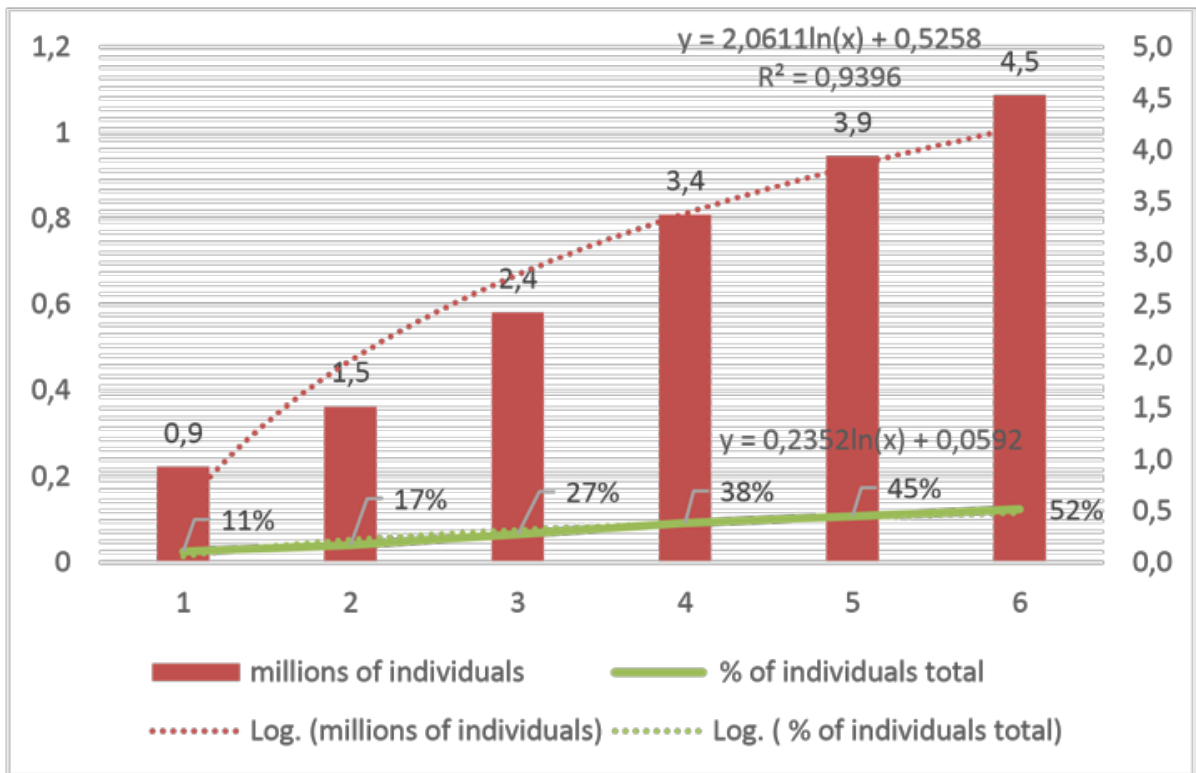

Fig. 2. Individuals using Internet Banking in 2007, 2009, 2011, 2013, 2015 and 2017, Source: Czech Statistical Office, [17], own processing

In a deeper analysis and use of statistical functions, it was subsequently found that Internet Banking has increasing trend. The logarithmic trend explains $93 \%$ of the variance. The linear trend explains over $95 \%$ of the variance.

Overall, Internet Banking uses 52\% of individuals in 2017. Of this, 55\% of males and $49 \%$ of women use the internet banking in the Czech Republic (see Figure 3).

\section{$\%$ of individuals total}

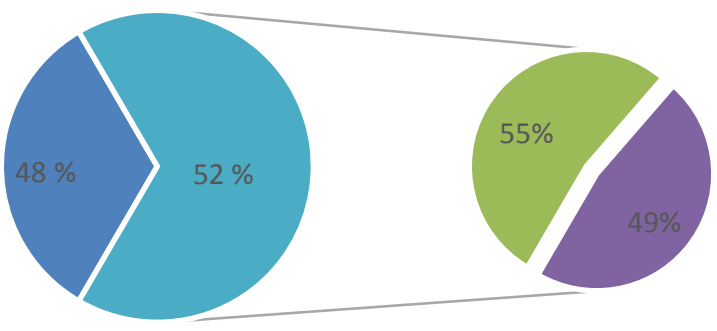

- Total - Males - Females

Fig. 3. Individuals using Internet Banking by gender in 2017, Source: Czech Statistical Office, [17], own processing 
$66 \%$ of individuals using the Internet in 2017 and $52 \%$ of individuals using Internet Banking in the Czech Republic. Interestingly, in the 16-24 age group, all who use the Internet are also using Internet banking. This trend, with a slight decrease, can be observed for the age groups of 25-54 years. Since the age of 55, there has been a steep decline in the use of Internet Banking. Only 12\% of individuals from age 65+ use Internet Banking. The Internet uses 36\% (see Figure 4).

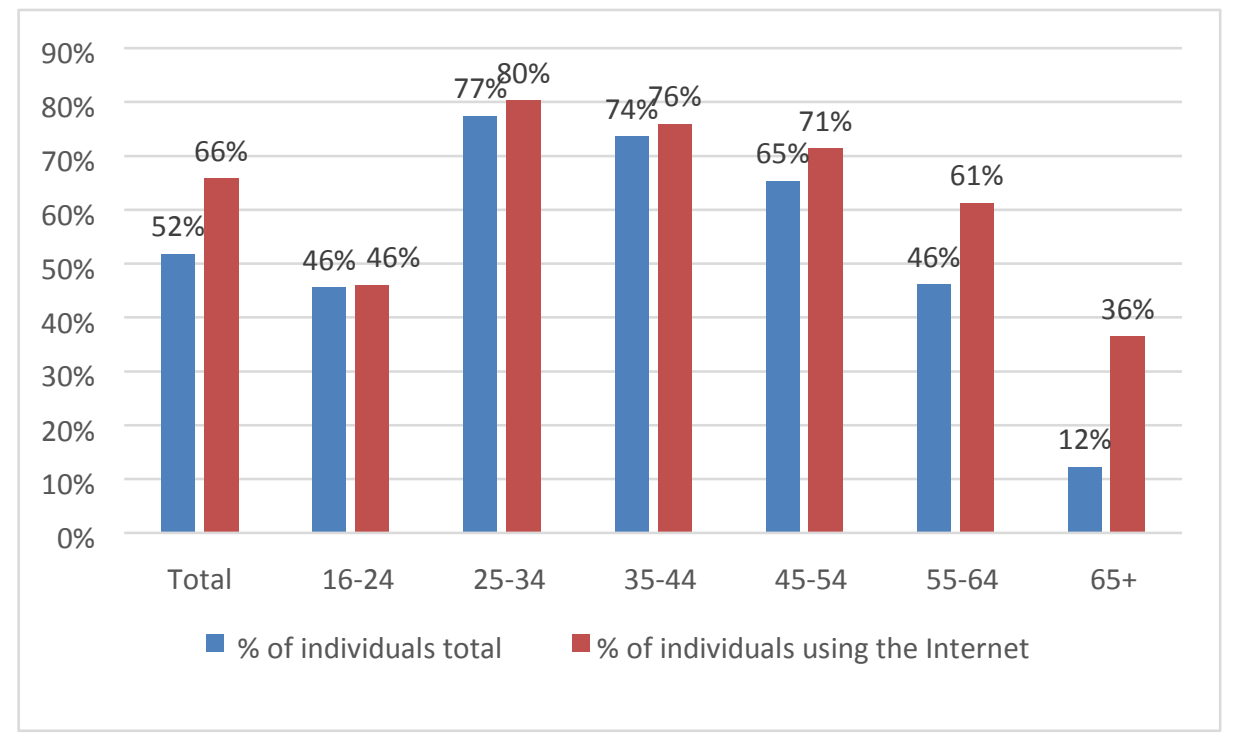

Fig. 4. Individuals using Internet Banking by age in 2017, Source: Czech Statistical Office, [17], own processing

Every year a growing number of individuals using Internet Banking also by completed education. Internet Banking is used mostly with people with higher education. 80\% of individuals with higher education uses Internet banking in 2017. For comparison, people with primary education use Internet banking only from 12.1\%. (See Figure 5). 


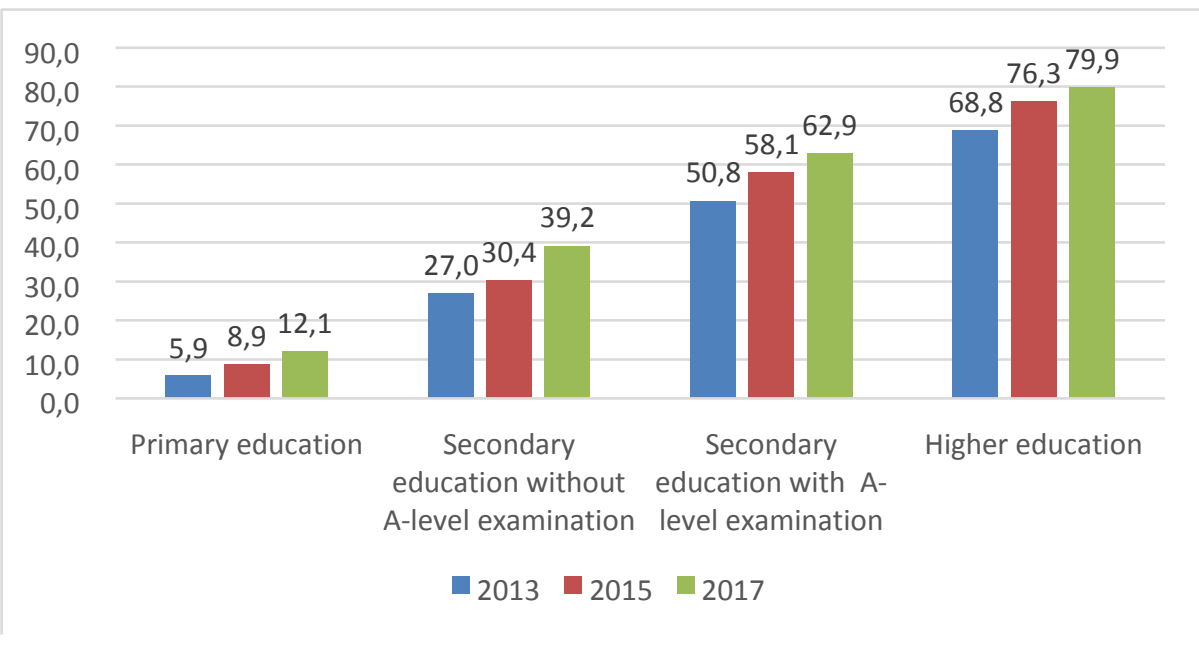

Fig. 5. Individuals using Internet Banking by completed education (25+), Source: Czech Statistical Office, [17], own processing

\subsection{Mobile Banking in the Czech Republic}

In April 2018, forty-six banks and branches of foreign banks operated in the Czech banking market according to the Czech National Bank. The analysis of mobile banking functions will be performed at ten selected banks according to the number of clients.The banks examined include: Česká spořitelna, ČSOB, Komerční banka, MONETA Money Bank, Fio banka, mBank, Air Bank, Raiffeisenbank, UniCredit Bank a Equa bank.

These banks are currently the largest total assets of the Czech banking sector (excluding mBank, which would be 11th and vice versa, would be SberBank).

Table 1. Number of clients in 2016 and 2017, [18, own processing]

\begin{tabular}{lcc}
\hline Bank & \begin{tabular}{c} 
Number of clients in \\
\cline { 2 - 3 }
\end{tabular} & $\begin{array}{c}\text { Number of clients in } \\
2017^{*}\end{array}$ \\
\hline Česká spořitelna & 4707000 & 4680000 \\
ČSOB & 2803000 & 2766000 \\
Komerční banka & 1654000 & 1654000 \\
Moneta Money Bank & 970000 & 1000000 \\
FIO bank & 670000 & 770000 \\
mBank & 63000 & 630000 \\
Air bank & 515000 & 596966 \\
Raiffeisen bank & 500000 & does not state \\
Unicredit bank & 350000 & 303000 \\
Equa bank & 250000 & 307000 \\
\hline
\end{tabular}

FIO Bank was the first in the Czech Republic to launch Internet Banking in 1998. In 2011, FIO Bank launched its first mobile application. 
The analysis confirms that currently eleven useful features are being promoted in mobile banking and new ones are still emerging [19]. Important features include: Open section:

- Fee calculator,

- Exchange rates,

- Branches,

- Contacts

- Search for ATMs and branches Secured section:

- Fingerprint, Touch ID (Reports, Overview of reports and details)

- Accounts (overview of balances on active accounts (current, savings and term) and their total by currency, Transaction history etc.)

- QR codes (Payment via QR codes)

- Reports (Overview of reports and details)

- Templates (Template overview, Template adding / editing/ deleting)

- Payment orders (Placing orders between your accounts, Placing single CZK payment orders within the Czech Republic, Placing single EUR payment orders to Slovakia, Placing EUR payment orders in the Eurozone (TARGET2), Placing foreign payment orders, Overview of "pending" payments (with maturity in the future), Overview of incomplete payments) [20]

- Mobile payment card management

- Arrangement of credit via mobile or via mobile application

- Opening a current account for a mobile phone or via mobile application

- Mobile cards for NFC mobile payments

- "Pay me" - a simple payment among people

\subsection{Use of social networks by banks}

The biggest commercial banks were selected into comparison. All of ten most important banks use Facebook, Instagram, Twitter, Linkedin and YouTube. Half of them do not use account on the Google+. Account on Google+ have Air bank, Equa bank, Česká spořitelna, Fio bank and Komerční banka (see Table 2).

Table 2. Use of social networks by banks in 2018, [own processing]

\begin{tabular}{cccccc}
\hline Bank & $\begin{array}{c}\text { Facebooo } \\
\mathrm{k}\end{array}$ & Instagram & Twitter & $\begin{array}{c}\text { YouTu } \\
\text { be }\end{array}$ & $\begin{array}{c}\text { Google } \\
+\end{array}$ \\
\hline $\begin{array}{c}\text { Česká } \\
\text { spořitelna }\end{array}$ & $\mathrm{X}$ & $\mathrm{X}$ & $\mathrm{X}$ & $\mathrm{X}$ & $\mathrm{X}$ \\
$\begin{array}{c}\text { ČSOB } \\
\text { Komerční }\end{array}$ & $\mathrm{X}$ & $\mathrm{X}$ & $\mathrm{X}$ & $\mathrm{X}$ & 0 \\
$\begin{array}{c}\text { banka } \\
\text { Moneta }\end{array}$ & $\mathrm{X}$ & $\mathrm{X}$ & $\mathrm{X}$ & $\mathrm{X}$ & 0 \\
Money Bank & & & & & \\
\hline $\begin{array}{l}\text { FIO bank } \\
\text { mBank }\end{array}$ & $\mathrm{X}$ & $\mathrm{X}$ & $\mathrm{X}$ & $\mathrm{X}$ & $\mathrm{X}$ \\
& & $\mathrm{X}$ & $\mathrm{X}$ & $\mathrm{X}$ & 0
\end{tabular}




\begin{tabular}{cccccc} 
Air bank & $\mathrm{X}$ & $\mathrm{X}$ & $\mathrm{X}$ & $\mathrm{X}$ & $\mathrm{X}$ \\
$\begin{array}{c}\text { Raiffeisen } \\
\text { bank }\end{array}$ & $\mathrm{X}$ & $\mathrm{X}$ & $\mathrm{X}$ & $\mathrm{X}$ & 0 \\
$\begin{array}{l}\text { Unicredit } \\
\text { bank }\end{array}$ & $\mathrm{X}$ & $\mathrm{X}$ & $\mathrm{X}$ & $\mathrm{X}$ & 0 \\
$\quad$ Equa bank & $\mathrm{X}$ & $\mathrm{X}$ & $\mathrm{X}$ & $\mathrm{X}$ & $\mathrm{X}$ \\
\hline
\end{tabular}

\section{Conclusion and discussion}

The aim of the first part of the article was to analyze the use of Internet banking in the European Union and especially in the Czech Republic. All the indicators surveyed had a growing trend and showed a growing trend in the use of Internet banking, although growth rates slowed down from 2015 onwards. Even so, the Czech Republic is above the EU average in using Internet Banking.

The second part analyzes the ten largest banks in the Czech Republic according to the number of clients. For these banks, it examines how the new features in its mobile banking and how it differs from the competition. The high competition in the banking market forces individual banks to offer constantly new features and services. It is a question to discussion whether all functions for clients are needed and how long they will be offered by banks.

\section{Acknowledgement}

The paper was written with the support of the specific project 6/2018 grant "DETERMINANTS OF COGNITIVE PROCESSES IMPACTING THE WORK

PERFORMANCE" granted by the University of Hradec Králové, Czech Republic. We would like to thank student Eliška Čonková for cooperation in the processing of the article.

\section{References}

1. Criterio (2014) Leadership of inquiry: building and sustaining capacity for school improvement. Educational Evaluation and Policy.

2. Peevers, G., Douglas, G., Marshall, D., Jack, M. (2010). On the role of SMS for transaction confirmation with IVR telephone banking. International Journal of Bank Marketing, Vol. 29 No. 3, 206-223, (2011)

3. Khalfan, A., Yaqoub, S.Y., AlRefaei, Y., Al-Hajery, M., (2006). Factors influencing the adoption of Internet banking in Oman: a descriptive case study analysis. International Journal of Financial Services Management 1 (2), 155-172.

4. Almogbil, A. (2005). Security, Perceptions, and Practices: Challenges facing Adoption of Online Banking in Saudi. Unpublished Ph.D. Thesis, George Washington University, Washington.

5. Omar, A.B., Sultan, N., Zaman, K., Bibi, N. (201). Customer Perception towards Online Banking Services: Empirical Evidence from Pakistan, Journal of Internet Banking and Commerce, Vol. 16 (2),

6. Hedvicakova, M. (2017). Key study of bank accounts for young people with using multicriteria optimization and fuzzy analysis. Applied Economics, Vol. 49 (36), 35993610 
7. Lin L, Shiqian W. Factors Influencing the Behavior Intention of E-Banking Transactions Through Mobile Phones in China, Journal of Internet Banking and Commerce, ISSN: 1204-5357, Retrieved from: http://www.icommercecentral.com/open-access/factors-influencing-thebehavior-intention-of-ebanking-transactions-through-mobile-phones-inchina.php?aid=86793

8. Soukal I., Draessler, J. (2012). Consumer desired price modeling - case study on the RCBS market. Procedia - social and behavioral sciences. 62(24.10.2012), s. 916-920. ISSN 1877-0428.

9. Takieddine, S., , Sun, J. (2015). Internet banking diffusion: A country-level analysis. Electronic Commerce Research and Applications, Vol. 14 (5), PP, 361-371, https://doi.org/10.1016/j.elerap.2015.06.001

10. Svobodova, L., Hedvicakova, M. Technological Readiness of the Czech Republic and the Use of Technology. Lecture Notes in Business Information Processing. Vol. 299, pp. 670-678 (2017)

11. Černohorská, L., Pilyavskyy, A., Aaronson, W. Comparative performance of the visegrad group banks for the period 2009-2013. E a M: Ekonomie a Management, vol. 20(2), pp. 175-187 (2017)

12. Vokoun, M. Characteristics of the innovation activities of firms in Europe: A critical review of international differences, Review of Economic Perspectives, vol. 17(3), pp. 239-262 (2017)

13. Hedvičáková M., Svobodová L., Dittrichová J., Král M. (2017). Financial literacy and money management of the pupils in the Czech education system, Proceedings of the 8th International Scientific Conference Finance and Performance of Firms in Science, Education and Practice, Tomas Bata University in Zlín, Zlín , pp. 244-259, ISBN 978807454-653-2

14. Eurostat (2017). Digital economy and society statistics - households and individuals, http://ec.europa.eu/eurostat/statisticsexplained/index.php?title=Digital_economy_and_society_statistics_-

_households_and_individuals, last accessed 2018/06/14

15. Eurostat, (2018). Internet banking on the rise, http://ec.europa.eu/eurostat/web/productseurostat-news/-/DDN-20180115-1, last accessed 2018/06/17

16. Eurostat, (2016). Archive: Internet access and use statistics - households and individuals, http://ec.europa.eu/eurostat/statisticsexplained/index.php?title=Archive:Internet_access_and_use_statistics_-

_households_and_individuals, last accessed 2018/06/17

17. Czech Statistical Office, (2018). Informační společnost v číslech - 2018, https://www.czso.cz/csu/czso/informacni-spolecnost-v-cislech, last accessed 2018/06/18

18. DuoFinance, (2018). Banky podle velikosti? Počty klientů a aktiva v roce 2018! https://www.duofinance.cz/banky-cr-podle-poctu-klientu, last accessed 2018/06/1

19. iDnes.cz, (2017). Analýza deseti bank: co už umí mobilní bankovnictví a co má úspěch., https://finance.idnes.cz/analyza-rijen-2017-co-umi-mobilni-bankovnictvismartbanking-10-bank-p8e-

/sporeni.aspx?c=A171017_075039_sporeni_sov\&strana=1\#space-a, last accessed 2018/06/8

20. Fio bank, (2018). Smartbanking, https://www.fio.cz/bankservices/smartbanking/functions, last accessed 2018/06/10 